\title{
Predisposing factors associated with obesity among adolescents-A case control study.
}

\author{
Nirmala $A^{1^{*}}$, Kanniammal $C^{1}$, Venkataraman $P^{2}$, Judie Arulappan ${ }^{3}$ \\ ${ }^{1}$ Department of Nursing, SRM College of Nursing, SRM Institute of Science and Technology, Tamil Nadu, India \\ ${ }^{2}$ Department of Medical Research, SRM Medical College and Research Center, SRM Institute of Science and \\ Technology, Tamil Nadu, India \\ ${ }^{3}$ Department of Nursing, College of Nursing, Sultan Qaboos University, Muscat, Oman
}

\begin{abstract}
Background: The risk factors of obesity changes around the world. Adolescence is identified as a critical period for the development of obesity related metabolic derangements. This study evaluated the predisposing factors of obesity among adolescent students in kancheepuram district, South India.

Methods: This case control study was conducted in Kancheepuram district between July 2017 to September 2017. A total of 1656 adolescent boys and girls between the age group of 12 to 15 years were randomly selected from 12 schools (4 public schools, 4 matriculation schools and 4 government schools). The cases were obese adolescents and the controls were non obese adolescents. Univariate and Multivariate logistic regression analysis was conducted, and odds ratios (ORs) and $95 \%$ confidence intervals (CIs) were calculated.

Results: Various lifestyle factors including behavioral, dietary and family factors were identified as predisposing factors also for obesity.

Conclusion: There is an urgent need to educate adolescents on the aspects of healthy food habits and desired lifestyles to prevent overweight/obesity and its associated ill effects.
\end{abstract}

Keywords: Metabolic problem, Pre disposing, Factors, Obesity, Adolescents, South India.

Accepted on September 22, 2018

\section{Introduction}

The prevalence of obesity is increasing around the world. World Health Organization defined overweight and obesity as abnormal or excessive accumulation of fat that may impair health [1]. At present the potential public health issue that is emerging, is the increasing incidence of childhood obesity in developing countries, and the resulting socioeconomic and public health burden that will be faced by these countries in the near future. Childhood and adolescence obesity is related to an increased adult morbidity and mortality by leading to a variety of conditions such as diabetes mellitus, hypertension, psychological disorders and social problems [2]. The pandemic of obesity has engulfed children and adolescents. It is estimated that 200 million school-aged children worldwide are overweight, of which 40-50 million are obese [3]. In India, the magnitude of overweight ranges from $9 \%$ to $27.5 \%$ and obesity ranges from $1 \%$ to $12.9 \%[4,5]$.

Obesity is a multi-factorial disorder. The fundamental cause of obesity and overweight is an energy imbalance between calories consumed and expended. The epidemic of obesity and overweight has been fuelled by an increase intake of energy dense food that are high in fats, coupled with an increase in physical inactivity due to the increasing sedentary work, changing modes of transportation and decrease in outdoor recreational activities [6]. Although studies have identified adverse consequences of obesity [7], research done to identify specific risk factors associated with obesity is limited in adolescent age group. Establishment of associated factors will be potentially useful in the holistic approach to the prevention of the rising prevalence of obesity and other noncommunicable cardiovascular diseases. Various studies conducted in India have revealed a rising trend in prevalence of overweight and obesity among children and adolescents. Thus, this study aimed to identify the predisposing factors of obesity among school going adolescents in Kancheepuram district, South India.

\section{Materials and Methods}

\section{Study design and participants}

This was a case control study conducted among adolescent students between 12 to 15 years to examine a broad range of possible determinants of obesity. The cases and controls were 
recruited from 12 schools (4 public schools, 4 matriculation schools and 4 government schools) in Kancheepuram district.

\section{Sample size}

The sample size was based on the prevalence of $5 \%$ and allowable error as $1 \%$, for $95 \%$ significance level. A total of 1656 students were randomly selected and the level of obesity was assessed based on Revised Indian Academy of Pediatrics
BMI-for-Age and Sex growth charts [8]. Controls (here after referred 'non-obese') included 1500 adolescents with healthy weight and BMI Cut-off between adult equivalent of 23 and 19 (here after referred 'non-obese'). Cases included 156 obese adolescents with BMI of Adult equivalent 27 cut-off (here after referred 'obese'). Exclusion criteria included underweight adolescents (Table 1).

Table 1. Identification of influencing demographic factors for more level of obese using univariate analysis.

\begin{tabular}{|c|c|c|c|c|c|c|c|}
\hline \multirow{3}{*}{ Demographic variable } & & \multicolumn{4}{|c|}{ BMI } & \multirow{3}{*}{ Chi square test } & \multirow{3}{*}{$\begin{array}{l}\text { Odds Ratio } \\
(95 \% \mathrm{Cl})\end{array}$} \\
\hline & & \multicolumn{2}{|c|}{$\begin{array}{l}\text { Normal } \\
(n=1500)\end{array}$} & \multicolumn{2}{|c|}{ Obese $(n=156)$} & & \\
\hline & & $\mathrm{n}$ & $\%$ & $n$ & $\%$ & & \\
\hline \multirow{2}{*}{ Age } & $12-13$ years & 913 & $60.9 \%$ & 74 & $47.4 \%$ & \multirow{2}{*}{$\begin{array}{l}X^{2}=10.58 \\
P=0.001\end{array}$} & \multirow{2}{*}{$1.7(1.2-2.4)$} \\
\hline & $14-15$ years & 587 & $39.1 \%$ & 82 & $52.6 \%$ & & \\
\hline \multirow{2}{*}{ Gender } & Male & 1017 & $67.8 \%$ & 75 & $48.1 \%$ & \multirow{2}{*}{$\begin{array}{l}X^{2}=24.47 \\
P=0.001\end{array}$} & \multirow{2}{*}{$2.3(1.6-3.2)$} \\
\hline & Female & 483 & $32.2 \%$ & 81 & $51.9 \%$ & & \\
\hline \multirow{2}{*}{ Level of education } & $6-7^{\text {th }} \mathrm{std}$ & 834 & $55.6 \%$ & 70 & $44.9 \%$ & \multirow{2}{*}{$\begin{array}{l}X^{2}=6.56 \\
P=0.01\end{array}$} & \multirow{2}{*}{$1.5(1.1-2.1)$} \\
\hline & $8-9^{\text {th }}$ std & 666 & $44.4 \%$ & 86 & $55.1 \%$ & & \\
\hline \multirow{2}{*}{ Type of school } & Govt. school & 540 & $36.0 \%$ & 32 & $20.5 \%$ & \multirow{2}{*}{$\begin{array}{l}X^{2}=14.99 \\
P=0.001\end{array}$} & \multirow{2}{*}{$2.2(1.5-3.3)$} \\
\hline & Private School & 960 & $64.0 \%$ & 124 & $79.5 \%$ & & \\
\hline \multirow{2}{*}{ Occupation of mother } & Housewife & 782 & $52.1 \%$ & 55 & $35.2 \%$ & \multirow{2}{*}{$\begin{array}{l}X^{2}=16.10 \\
P=0.001\end{array}$} & \multirow{2}{*}{$2.0(1.4-2.8)$} \\
\hline & Employed & 718 & $47.9 \%$ & 101 & $64.8 \%$ & & \\
\hline \multirow{2}{*}{ Income } & $<$ Rs 21,438 & 849 & $56.6 \%$ & 73 & $46.8 \%$ & \multirow{2}{*}{$\begin{array}{l}X^{2}=5.50 \\
P=0.02\end{array}$} & \multirow{2}{*}{$1.5(1.1-2.1)$} \\
\hline & >Rs 21,438 & 651 & $43.4 \%$ & 83 & $53.2 \%$ & & \\
\hline
\end{tabular}

Table 2. Identification of influencing life style factors for more level of obese using univariate analysis.

\begin{tabular}{|c|c|c|c|c|c|c|c|}
\hline \multirow{3}{*}{ Demographic variables } & & \multicolumn{4}{|c|}{ BMI } & \multirow[t]{3}{*}{ Chi square test } & \multirow{3}{*}{$\begin{array}{l}\text { Odds Ratio } \\
(95 \% \mathrm{Cl})\end{array}$} \\
\hline & & \multicolumn{2}{|c|}{ Normal $(n=1500)$} & \multicolumn{2}{|c|}{ Obese $(n=156)$} & & \\
\hline & & $\mathrm{n}$ & $\%$ & $\mathrm{n}$ & $\%$ & & \\
\hline \multirow{2}{*}{ Daily intake of breakfast } & Regular & 898 & $59.9 \%$ & 58 & $37.2 \%$ & \multirow{2}{*}{$\begin{array}{l}X^{2}=28.80 \\
P=0.001\end{array}$} & \multirow{2}{*}{$2.5(1.8-3.5)$} \\
\hline & Irregular & 602 & $40.1 \%$ & 98 & $62.8 \%$ & & \\
\hline \multirow{2}{*}{$\begin{array}{l}\text { Frequency of intake of high fiber } \\
\text { diet per day }\end{array}$} & more times & 1029 & $68.6 \%$ & 70 & $44.9 \%$ & \multirow{2}{*}{$\begin{array}{l}X^{2}=35.61 \\
P=0.001\end{array}$} & \multirow{2}{*}{$2.7(1.9-3.7)$} \\
\hline & None & 471 & $31.4 \%$ & 86 & $55.1 \%$ & & \\
\hline \multirow{2}{*}{$\begin{array}{l}\text { Frequency of snacking on 'junk' } \\
\text { food per day }\end{array}$} & None & 340 & $22.7 \%$ & 22 & $14.1 \%$ & \multirow{2}{*}{$\begin{array}{l}X^{2}=6.06 \\
P=0.01\end{array}$} & \multirow{2}{*}{$1.8(1.1-2.8)$} \\
\hline & more times & 1160 & $77.3 \%$ & 134 & $85.9 \%$ & & \\
\hline \multirow{2}{*}{$\begin{array}{l}\text { Frequency of drinking } \\
\text { sweetened beverages per day }\end{array}$} & None & 829 & $55.3 \%$ & 23 & $14.7 \%$ & \multirow{2}{*}{$\begin{array}{l}X^{2}=92.89 \\
P=0.001\end{array}$} & \multirow{2}{*}{$7.1(4.5-11.3)$} \\
\hline & One to two times & 671 & $44.7 \%$ & 133 & $85.3 \%$ & & \\
\hline \multirow{2}{*}{$\begin{array}{l}\text { Frequency of eating fast food } \\
\text { items per day }\end{array}$} & None & 848 & $56.5 \%$ & 32 & $20.5 \%$ & \multirow{2}{*}{$\begin{array}{l}X^{2}=73.62 \\
P=0.001\end{array}$} & \multirow{2}{*}{$5.0(3.4-7.5)$} \\
\hline & more times & 652 & $43.5 \%$ & 124 & $79.5 \%$ & & \\
\hline
\end{tabular}




\begin{tabular}{|c|c|c|c|c|c|c|c|}
\hline \multirow{2}{*}{$\begin{array}{l}\text { Frequency of eating snacks \& } \\
\text { meals while watching TV }\end{array}$} & Sometimes/often & 1115 & $74.3 \%$ & 68 & $43.6 \%$ & \multirow{2}{*}{$\begin{array}{l}X^{2}=65.45 \\
P=0.001\end{array}$} & \multirow{2}{*}{$3.8(2.7-5.3)$} \\
\hline & Always & 385 & $25.7 \%$ & 88 & $56.4 \%$ & & \\
\hline \multirow{2}{*}{$\begin{array}{l}\text { Physical activity done per day } \\
\text { (hrs /day) }\end{array}$} & Yes & 1383 & $92.2 \%$ & 129 & $82.7 \%$ & \multirow{2}{*}{$\begin{array}{l}X^{2}=16.08 \\
P=0.001\end{array}$} & \multirow{2}{*}{$2.4(1.6-3.9)$} \\
\hline & No & 117 & $7.8 \%$ & 27 & $17.3 \%$ & & \\
\hline \multirow{2}{*}{ Total hours of sleep per day } & $>8 h$ & 953 & $63.5 \%$ & 73 & $46.8 \%$ & \multirow{2}{*}{$\begin{array}{l}X^{2}=16.79 \\
P=0.001\end{array}$} & \multirow{2}{*}{$1.9(1.4-2.8)$} \\
\hline & $<8 \mathrm{~h}$ & 547 & $36.5 \%$ & 83 & $53.2 \%$ & & \\
\hline \multirow{2}{*}{ Personnel health problem } & No & 1427 & $95.1 \%$ & 140 & $89.7 \%$ & \multirow{2}{*}{$\begin{array}{l}X^{2}=8.07 \\
P=0.01\end{array}$} & \multirow{2}{*}{$2.2(1.3-3.9)$} \\
\hline & Yes & 73 & $4.9 \%$ & 16 & $10.3 \%$ & & \\
\hline \multirow{2}{*}{ Attained puberty } & No & 1215 & $81.0 \%$ & 94 & $60.3 \%$ & \multirow{2}{*}{$\begin{array}{l}X^{2}=36.70 \\
P=0.001\end{array}$} & \multirow{2}{*}{$2.8(2.0-3.9)$} \\
\hline & Yes & 285 & $19.0 \%$ & 62 & $39.7 \%$ & & \\
\hline
\end{tabular}

\section{Anthropometry}

Body weight and height were measured within the school premises, in an isolated area which did not affected the routing daily activity of the school and secured the privacy of the participants, by the investigator. Subjects were asked to remove shoes and empty their pockets, before body weight was measured using calibrated electronic scale placed on an even concrete floor accurate to the nearest $0.1 \mathrm{~kg}$. Height was measured to the nearest $0.1 \mathrm{~cm}$ with an upright plastic portable stadiometer. BMI was calculated as weight in kilograms divided by height squared in meters $\left(\mathrm{kg} / \mathrm{m}^{2}\right)$.

\section{Data collection}

The interviewer administered questionnaire to collect the information from the subjects. The questionnaire was designed to capture the dietary, behavioural and socioeconomic factors associated with obesity, from the individuals .The validity and reliability of the questionnaire were assessed. This study was also approved by the Institutional Ethical committee. Informed consent was obtained from the parents and assent from children before the data was collected.

\section{Data analysis}

The logistic regression analysis was conducted to control the effect of various risk factors on obesity. Adjusted odd ratios (ORS) were calculated to determine the association between obesity and predisposing factors by applying a significance level of 0.05 using the SPSS Statistics Software.

\section{Results}

Univariate analysis identified aged adolescents, Female gender, Private school adolescents, Employed mothers adolescents and high income family adolescents obese than non-obese. Unadjusted odds ratio was given with $95 \%$ confidence interval. The table also shows statistically significant association between obesity and age of adolescents $(p<0.001)$, female gender $(\mathrm{p}<0.001$, private school students $(\mathrm{p}<0.001)$, employment status of mother $(p<0.001)$, and monthly family income $(\mathrm{p}<0.02)$.
Table 2 shows statistically significant association between dietary factors and obesity. The dietary factors include skipping breakfast $(\mathrm{p}<0.001)$, lack of intake of high fiber diet $(\mathrm{P}<0.001)$, intake of sweetened beverages $(\mathrm{P}<0.001)$, 'junk' foods $(\mathrm{P}<0.01)$, fast food items $(\mathrm{P}<0.001)$ and snacking while watching TV $(\mathrm{P}<0.001)$. This study also shows significant association between behavioral factors and obesity. The behavioral factors include lack of physical activity $(\mathrm{P}<0.001)$ and lack of sleep $(\mathrm{P}<0.001)$. Health problems of adolescents $(\mathrm{P}<0.01)$ and puberty $(\mathrm{P}<0.001)$ also showed statistically significant association (Table 3 ).

Table 3. Identification of influencing life style factors for more level of obese using Multivariate logistic regression.

\begin{tabular}{lllll}
\hline & Univariate analysis & $\begin{array}{c}\text { Multivariate } \\
\text { analysis }\end{array}$ \\
\cline { 2 - 5 } & $\begin{array}{l}\text { p- } \\
\text { value }\end{array}$ & $\begin{array}{l}\text { Unadjusted } \\
\text { OR (95\%Cl) }\end{array}$ & $\begin{array}{l}\text { p- } \\
\text { value }\end{array}$ & $\begin{array}{l}\text { Adjusted } \\
\text { OR (95\%Cl) }\end{array}$ \\
\hline $\begin{array}{l}\text { Daily intake of breakfast } \\
\text { (Irregular vs. Regular) }\end{array}$ & 0.001 & $2.5(1.8-3.5)$ & 0.001 & $2.5(1.7-3.7)$ \\
\hline $\begin{array}{l}\text { Intake of high fiber diet per day } \\
\text { (None vs. more times) }\end{array}$ & 0.001 & $2.7(1.9-3.7)$ & 0.02 & $1.6(1.1-2.3)$ \\
\hline $\begin{array}{l}\text { snacking on 'junk' food per day } \\
\text { (None vs. more times) }\end{array}$ & 0.01 & $1.8(1.1-2.8)$ & 0.18 & $1.5(0.8-2.5)$ \\
\hline $\begin{array}{l}\text { drinking sweetened beverages } \\
\text { per day (None vs. More times) }\end{array}$ & 0.001 & $7.1(4.5-11.3)$ & 0.001 & $5.8(3.4-9.9)$ \\
\hline $\begin{array}{l}\text { eating fast food items per day } \\
\text { (None vs. more times) }\end{array}$ & 0.001 & $5.0(3.4-7.5)$ & 0.01 & $1.8(1.1-2.9)$ \\
\hline $\begin{array}{l}\text { eating snacks \& meals while } \\
\text { watching TV } \\
\text { (>Always vs. sometimes) }\end{array}$ & 0.001 & $3.8(2.7-5.3)$ & 0.001 & $2.0(1.3-3.1)$ \\
\hline $\begin{array}{l}\text { Physical activity done per day } \\
\text { (No vs. Yes) }\end{array}$ & 0.001 & $2.4(1.6-3.9)$ & 0.001 & $4.0(2.2-7.1)$ \\
\hline $\begin{array}{l}\text { Personnel health problem } \\
\text { (Yes vs. No) }\end{array}$ & 0.001 & $1.9(1.4-2.8)$ & 0.55 & $0.9(0.6-1.3)$ \\
\hline & $2.2(1.3-3.9)$ & 0.23 & $1.5(0.8-3.0)$ \\
\hline
\end{tabular}


Attained puberty(Yes vs. No)

$0.001 \quad 2.8(2.0-3.9) \quad 0.001 \quad 2.6(1.8-3.9)$

Univariate analysis identifies irregular daily intake of breakfast of high fiber diet, Frequent snacking on 'junk' food, drinking sweetened beverages, frequent eating of fast food items, more times of eating snacks \& meals while watching TV, No physical activity, $<8 \mathrm{~h}$ sleeping per day, Personnel health problems, and puberty among obese adolescents than nonobese. Unadjusted odds ratio was given with $95 \%$ confidence interval. Multivariate analysis logistic regression identifies increased number of obesity among adolescents with Irregular intake of breakfast, lack of intake of high fiber diet , drinking sweetened beverages per day, more times of eating fast food items per day, more times of eating snacks \& meals while watching TV, physical activity and puberty. Adjusted odds ratio was given with $95 \%$ confidence interval.

\section{Discussion}

The objective of the study was to identify the predisposing factors associated with obesity. Present study identified demographic factors such as children above 13 years (AOR: $1.7 ; 95 \% \mathrm{CI}=1.2-2.4$ ) and female gender (AOR:2.3; 95\% $\mathrm{CI}=1.6-3.2$ ) as predisposing factors of obesity. These results were supported by Misra et al. [9]. This data was also supported by Katulanda et al. [10]. Our study results highlighted that adolescents from high family income were at a higher risk (AOR: 1.5; 95\% $\mathrm{CI}=1.1-2.1$ ) of being obese than those from low income [11].This is the normal trend seen in economies transition as people of affluent strata have more purchasing power to buy refined, calorie dense food in contrast to developed nations where fruits and vegetables are more expensive and high sugar and fat containing foods are available at a lower price. Private school students and employment status of mother were also identified as predisposing factor of obesity.

Present study identified dietary factors, family factors, behavioral factors, health problems and puberty as predisposing factors of obesity. Identified dietary factors in our study were, skipping breakfast (AOR 2.5, 95\% CI=1.7-3.7), less intake of high fiber diet (AOR:1.6, 95\% CI=1.1-2.3), frequent intake of junk foods (AOR 1.5, 95\% $\mathrm{CI}=0.8-2.5$ ) and sweetened beverages (AOR: 5.8, 95\% CI=3.4-9.9). Always snacking while watching TV also increased the risk of obesity 2 times higher (AOR:2.0, 95\% CI=1.3-3.1). A nationally representative cross-sectional study [12] identified physical inactivity, skipping breakfast, inadequate consumption of green leafy vegetables and fruits and increased television viewing as potential challenges faced by adolescents. This information was consistent with our study.

In our study, $129(82.7 \%)$ adolescents did not participate in any physical activities; only $27(17.3 \%)$ of the obese adolescents reported performing some regular activities. These results were supported by Agazzi et al. [13]. Their study emphasized that, non-obese adolescents reported regular physical activity compared to their obese counterparts. Our study findings showed that, less hours of sleep (AOR:0.9, 95\% CI=0.6-1.3) per day leads to obesity. This data was similar to the study by George et al. [14]. According to their study findings, among the influencing factors of obesity, sleeping time was found to be significant $(p=0.01)$. Adolescents with health problems (AOR:1.5, 95\% $\mathrm{CI}=0.8-3.0$ ) were also considered as predisposing factors of obesity. Our study showed an influence of birth order on obesity. Although, it was not statistically associated with obesity in our study, similar study results showed significant association between first-born status of the child and obesity [15].

Obesity and sedentary life style are closely related. In this study, $34(21.8 \%)$ obese adolescents reported, screen time more than 4 day and 78 (49\%) obese adolescents reported screen time $>2$ day. Similar to a published study [16] computer use was more prevalent among obese children. A study conducted among adolescent school children in India revealed that the risk of overweight was seven times higher among those who had screen time $\geq 4 \mathrm{~h} /$ day [17]. Puberty was also considered as a predisposing factor of obesity. Present study shows that obesity was marginally higher among the pubertal age group, i.e., 13 to 15 years of age, as observed in similar studies conducted in Hyderabad [18]. Puberty increases the chance of obesity 2.6 times higher (AOR:2.6, 95\% CI=1.8-3.9) because of increased adipose tissue and overall body weight in children during puberty. It has been reported earlier that the number of fat cells increases during periods of rapid growth up to 16 years of age, after which increased fat ordinarily accumulates by increasing size of the cells already present.

\section{Conclusion}

The major conclusion drawn from this study is that low levels of physical activity, watching television, intake of junk foods and fewer intakes of fruits and vegetables were associated with a higher prevalence of obesity. Thus, participation in household activities and regular physical exercise could help in lowering the prevalence of overweight. Therefore, the role of physical activity, games, and sports should be emphasized, and facilities should be provided for outdoor games in schools, with compulsory hours of sports and games. There is an urgent need to educate adolescents on the aspects of healthy food habits and desired lifestyles to prevent overweight/obesity and its associated ill effects.

\section{Implications}

- Health care members play a vital role in health promotion by increasing public awareness on identification of obesity and by training the teachers regarding early recognition of issues in management of obesity.

- Health care administrators can place recommendations to the authorities regarding initiation in creating policies and plans in providing education to the children, parents and teachers for improving their lifestyle behaviors to prevent obesity.

- Researchers are also motivated to develop more reliable approaches to generate data that can be used in policy making and organization of services. 


\section{References}

1. Shivpuri A, Shivpuri A, Sharma S. Childhood obesity: Review of a growing problem. Int $\mathrm{J}$ Clin Pediatric Dentistry 2012; 5: 237.

2. Pinhas-Hamiel O, Dolan LM, Daniels SR, Standiford D, Khoury PR, Zeitler P. Increased incidence of non-insulindependent diabetes mellitus among adolescents. J Pediatrics 1996; 128: 608-615.

3. Sidiq T, Khan N, Bhat BA. A study on eating habits and risk factors associated with obesity among adolescence studying in private schools in district Pulwama, Kashmir. ARC J Nutri Growth 2015; 1: 1-6.

4. World Health Organization. Obesity: preventing and managing the global epidemic. World Health Organization; 2000.

5. Bose K, Bisai S, Mukhopadhyay A, Bhadra M. Overweight and obesity among affluent Bengalee schoolgirls of Lake Town, Kolkata, India. Maternal \& Child Nutri 2007; 3: 141-145.

6. Mokdad AH, Bowman BA, Ford ES, Vinicor F, Marks JS, Koplan JP. The continuing epidemics of obesity and diabetes in the United States. JAMA 2001; 286: 1195-200.

7. Wickramasinghe VP, Arambepola C, Bandara P, Abeysekera M, Kuruppu S, Dilshan P, Dissanayake BS. Distribution of obesity-related metabolic markers among 5-15 year old children from an urban area of Sri Lanka. Ann Hum Biol 2013; 40: 168-174.

8. Khadilkar V. Revised IAP growth charts for height, weight and body mass index for 5-18 year old children. Indian Pediatr 2015; 52: 47-55.

9. Misra A, Shah P, Goel K, Hazra DK, Gupta R, Seth P, Tallikoti P, Mohan I, Bhargava R, Bajaj S, Madan J. The high burden of obesity and abdominal obesity in urban Indian schoolchildren: a multicentric study of 38,296 children. Annal Nutri Metabol 2011; 58: 203-211.

10. Katulanda P, Jayawardena MA, Sheriff MH, Constantine GR, Matthews DR. Prevalence of overweight and obesity in Sri Lankan adults. Obes Rev 2010; 11: 751-756.

11. Wang Y. Cross-national comparison of childhood obesity: the epidemic and the relationship between obesity and socioeconomic status. Int $\mathrm{J}$ Epidemiol 2001; 30: 1129-1136.

12. Pérez A, Hoelscher DM, Springer AE, Brown HS, Kelder $\mathrm{SH}$, Barroso CS, Castrucci BC. Physical activity, watching television, and the risk of obesity in students, texas, 2004-2005. Prevent Chronic Dis 2011.

13. Agazzi H, Armstrong K, Bradley-Klug KL. BMI and physical activity among at-risk sixth-and ninth-grade students, hillsborough county, florida, 2005-2006. Prevent Chronic Dis 2010.

14. George S, Binu J, Joseph BB. A study on the prevalence of overweight and obesity and its influencing factors in rural adolescent school going children in Kerala, India. Int J Curr Res Rev 2012; 4: 89-99.

15. Celi F, Bini V, De Giorgi G, Molinari D, Faraoni F, Di Stefano G, Bacosi ML, Berioli MG, Contessa G, Falorni A. Epidemiology of overweight and obesity among school children and adolescents in three provinces of central Italy, 1993-2001: study of potential influencing variables. Eur J Clin Nutr 2003; 57: 1045-1051.

16. Wake M, Hesketh K, Waters E. Television, computer use and body mass index in Australian primary school children. J Paediatr Child Health 2003; 39: 130-134.

17. Kotian MS, S GK, Kotian SS. Prevalence and determinants of overweight and obesity among adolescent school children of South karnataka, India. Indian J Community Med 2010; 35: 176-178.

18. Laxmaiah A, Nagalla B, Vijayaraghavan K, Nair M. Factors affecting prevalence of overweight among 12-to 17-year-old urban adolescents in Hyderabad, India. Obesity 2007; 15: 1384-1390.

\section{${ }^{*}$ Correspondence to}

Nirmala A

Department of Nursing

SRM College of Nursing

SRM Institute of Science and Technology

India 